\title{
Determination of Location and Depth of Mineral Rocks at Olode Village in Ibadan, Oyo State, Nigeria, Using Geophysical Methods
}

\author{
Akintayo O. Ojo, Toyin O. Omotoso, and Olorunyomi J. Adekanle \\ Department of Physics, University of Ibadan, Ibadan, Nigeria \\ Correspondence should be addressed to Akintayo O. Ojo; akintayoojo@yahoo.com
}

Received 7 February 2014; Revised 15 June 2014; Accepted 20 June 2014; Published 16 July 2014

Academic Editor: Salvatore Piro

Copyright (C) 2014 Akintayo O. Ojo et al. This is an open access article distributed under the Creative Commons Attribution License, which permits unrestricted use, distribution, and reproduction in any medium, provided the original work is properly cited.

\begin{abstract}
Magnetic and resistivity geophysical methods were used to investigate the location and depth of mineral rocks at Olode village, Oyo State, Nigeria. 80 magnetic data points were acquired in 10 profiles using G-816 proton precession magnetometer with $10 \mathrm{~m}$ spacing in between each profiles and $10 \mathrm{~m}$ stations interval. After correcting diurnal variations, the raw magnetic data obtained were plotted as 2D and 3D magnetic contour maps. The residual anomalies obtained were plotted against distance using Microsoft Excel, and Peter's half-slope method was used to find the depth to the magnetic sources. The magnetic signature obtained show considerable varying amplitude from a minimum value of $155.3 \mathrm{nT}$ at a depth of $6.37 \mathrm{~m}$ to a maximum value of $670.3 \mathrm{nT}$ at a depth of $6.25 \mathrm{~m}$. Resistivity data were obtained using Campus Tiger resistivity meter and 9 VESs were acquired using Schlumberger configuration. All VESs were $150 \mathrm{~m}$ long, $75 \mathrm{~m}$ on each side of the referenced points which were $10 \mathrm{~m}$ apart. VESs 1-4 and 7-9 are underlined with rocks of high conductivity and susceptibility values. VESs 5 and 6 show rocks with low conductivity and susceptibility values. The results of these geophysical methods show that there are rocks with high magnetic susceptibility and conductivity values from the centre towards the eastern region of the study area and low magnetic susceptibility and conductivity values at the western region. On the average, the depths of these rocks from the surface fall in the interval of $5.80 \mathrm{~m}$ to $6.72 \mathrm{~m}$.
\end{abstract}

\section{Introduction}

Geophysics plays a large part in a multitude of disciplines. Geophysics is a technique which has recently begun to be used by a number of disciplines to give information about the underlying ground without having to engage in invasive digging of the area. It has been used to help solve practical environmental, geotechnical, and exploration problems. The typical scenario is first to identify the physical property, that is, diagnostic of the sought geologic structure or buried object. The appropriate geophysical survey is then designed and field data are acquired and plotted. In some cases, the information needed to solve the problem may be obtained directly from these plots, but in most cases more information about the subsurface is required $[1,2]$.

The surface of the earth has provided the setting for most of human endeavours throughout the history of civilization, and these activities have been profoundly affected by the largely invisible characteristics of the immediate subsurface. Human development has depended heavily on resources obtained from both near surface (as in construction materials) and hundreds to thousands of meters deep (as in metalliferous ores and petroleum based products). We also use water from subsurface aquifers for industrial and domestic purposes; we deposit much of our waste within the near subsurface and build structures that must interface safely with these shallow regions $[3,4]$.

In relation to these activities, subsurface characteristics of particular interest to earth scientists include the location, distribution, depth and structure of rock types, grain size distribution and material strength, porosity, and permeability, to name a few. The earth's inherent complexity can make it difficult or impossible to infer these characteristics from direct observation. Therefore, they often must be inferred from 
the distribution of more fundamental physical properties such as density, electrical conductivity, magnetic susceptibility, and acoustic impedance. These basic properties can be measured via geophysical surveys that record the earth's response to various types of natural or artificial signals $[5,6]$.

The development of geophysics has been evolving since the 1950s after the Second World War, and new methods of automating geophysics, such as resistivity and magnetometry, are being developed now [7]. The study of the earth's magnetism is the oldest branch of geophysics. It has been known for more than three centuries that the earth behaves as large and somewhat irregular magnet [4]. However, the ground magnetic study is used for detail mapping in order to understand the subsurface geology of an area. The technique requires measurements of the amplitude of magnetic components at discrete points along traverses distributed regularly throughout the survey area of interest. In ground magnetic study, three components are measured which are horizontal, vertical, and total components. The vertical components and the total components are mostly used in the past studies to delineate faults, fractures, depth to magnetic basement, and other geological structures [8]. The magnetic method is very suitable for locating buried magnetite ore bodies because of their high magnetic susceptibility [9].

Electrical resistivity mapping techniques have been employed by many researchers in Nigeria and other parts of the world in identifying and delineating different geoelectric layers. Out of the known geophysical prospecting methods, the electrical method happen to be the most widely used geophysical method in engineering studies, environmental assessment, and hydrogeological investigation [4]. A principal advantage of the electrical resistivity method is that quantitative modeling is possible using either computer software or published master curves. The resulting models can provide accurate estimates of depths, thicknesses, and electrical resistivity of subsurface layers. The layer electrical resistivity can then be used to estimate the electrical resistivity of the saturating fluid, which is related to the total concentration of dissolved solids in the fluid. Limitations of using the electrical resistivity method are largely due to site characteristics, rather than any other factors that may be caused due to the resistivity method or configuration used [7].

Magnetic and resistivity geophysical techniques have found a wide range of applications in mineral exploration and geotechnical work $[4-6,8,10-13]$. These techniques are known as fast, high resolution, noninvasive, and costeffective techniques. The recent advances in electronics and medicine have increased the demand for rare metal (tantalum-niobium), that is, (Ta-Nb), which is used in making capacitors, surgical sutures, and implants, such as artificial joints. Others are used in making heat conductor in electric iron (mica), sculptures, bricks, and so on. The increase in global demand for these minerals especially the rare metals (Ta-Nb-Sn), that is, (tantalum-niobium-tin), has led to the renewed interest in the search for economically viable deposits in Nigeria [14-21].

In lieu of the above, magnetic and electrical geophysical techniques were used to identify the location and depth of formation of mineral rocks such as beryl, mica, feldspar, tourmaline, columbite, and tantalite in the study area.

\section{Geological Settings of the Study Area}

The study area is in Olode village, Ibadan, South West Local Government of Oyo State, Southwestern Nigeria. It is bounded by latitudes $7.1910^{\circ} \mathrm{N}$ to $7.1915^{\circ} \mathrm{N}$ and longitudes $3.9245^{\circ} \mathrm{E}$ to $3.9279^{\circ} \mathrm{E}$. The area is underlined by Precambrian rocks typical of the basement complex of Southwestern Nigeria [22] and it covers about $150 \mathrm{~m} \times 150 \mathrm{~m}$.

Geologically, Olode village falls within the crystalline basement complex of south western Nigeria, and to the rest of West African Craton, Olode village lies in the region of late Precambrian to early Proterozoic orogenesis. The basement complex of Southwestern Nigeria predominantly composed of migmatite and granitic gneiss; quartzite; slightly migmatised to unmigmatised metasedimentary schist and metaigneous rocks; charnockite; gabbro and diorite; and the members of the older granite suite, mainly granites, granodiorites, and syenites. Oyo State is composed of the migmatite-gneiss, quartzite, calc-silicate rocks, biotitehornblende schist, and amphibolites. Minor rock types are found within these gneisses and older granites. The minor rock types include pegmatite composed of microcline and quartz, which are widespread throughout the crystalline basement complex of Southwestern Nigeria. The pegmatites are, however, conspicuously absent from the main area of the slightly migmatised to unmigmatised paraschists and metaigneous rocks. The pegmatites in the gneisses may be conformable, but they are more commonly crosscutting. The quartz veins and lenses occur in all the major rock types of the basement complex and they are small varying in thickness from a few millimeters to a meter. They show great irregularities in their form and are seen in places as tinny or coarse stone. Dolente dykes are also associated with the gneisses and older granites, occurring as tabular, unmetamorphosed bodies crosscutting the foliation in the host rocks and are regarded by [22] as the youngest member of the basement complex. They range in thickness from about a few millimeters to half a meter. They trend northeast to southwest and east-northeast to west-southwest $[3,4,23$, 24]. The study area is underlined mainly by undifferentiated gneiss complex vein (Figure 1).

\section{Theory}

3.1. Magnetic Method. The origin of the earth's magnetism is commonly believed to be the liquid core, which cools at the outside as a result of which material becomes denser and sinks towards the inside of the outer core and new warm liquid matter rises to the outside; thus, convection currents are generated by liquid metallic matter which move through a weak cosmic magnetic field which subsequently generates induction currents [25]. It is this induction current that generate the earth's crust magnetic field. Most rocks of the earth's crust contain crystals with magnetic minerals; thus most rocks have a certain amount of magnetism, 


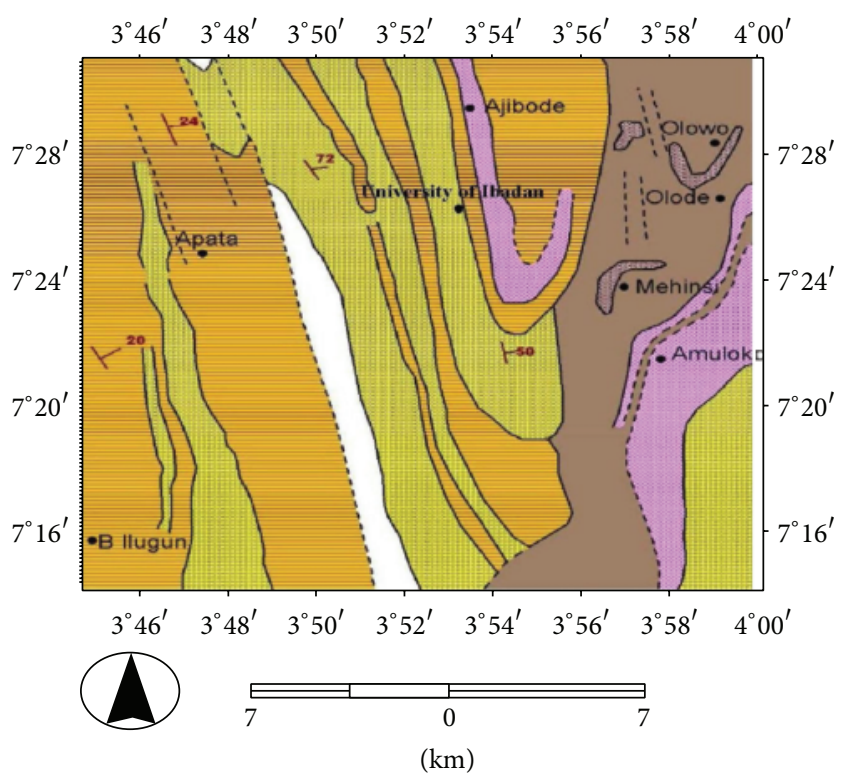

Explanation

$\square$ Pegmatite and quartz vein

E Quartzite quartz schist

- Granite gneiss

= Migmatite and banded gneiss

- Undifferentiated gneiss complex

Amphibolite

_ Geological boundary

$\angle$ Strike and dip

- - - Fault

- Settlement

FIgURE 1: Generalized geological map of Ibadan [23].

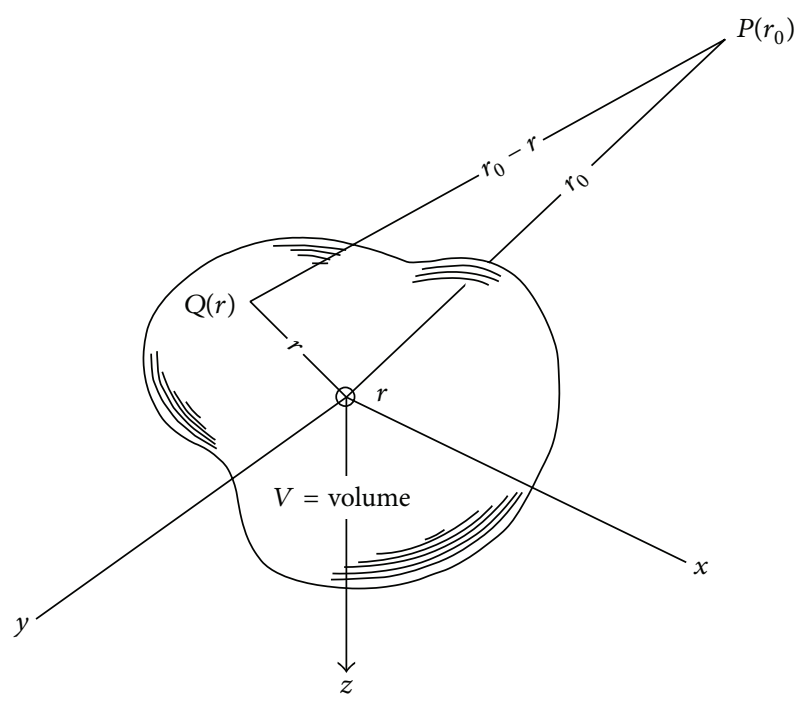

Figure 2: Magnetic scalar potential.

which usually has two components induced by the magnetic field present while taking measurement, and remnant which formed during geologic history [26].

The magnetic scalar potential is due to a continuous distribution of matter; for example, earth may be calculated at an external point $P$ (Figure 2) [26,27]. If the material that fills the volume $V$ has a continuous distribution of magnetic dipole moment per unit volume, then

$$
\vec{j}=\frac{\vec{m}}{v} .
$$

The magnetic potential $A$ of a dipole at point $P$ outside the volume $V$ with moment $m$ is given by

$$
A=\frac{m \cos \theta}{r^{2}}-\vec{m} \cdot \vec{\nabla}\left[\frac{1}{r}\right] .
$$

Integrating (2) gives

$$
A=-\int_{V} \vec{J} \cdot \vec{\nabla}\left|\frac{1}{\vec{r}-\vec{r}_{0}}\right| d v,
$$

but $d v=d^{3} r_{0}$. Consider

$$
A=-\int_{V} \vec{J} \cdot \vec{\nabla}\left|\frac{1}{\vec{r}-\vec{r}_{0}}\right| d^{3} r_{0} .
$$

The total magnetic field intensity at point $P$ outside the volume $V$ is given as

$$
\vec{H}=-\vec{\nabla} A .
$$

Putting (4) in (5) gives

$$
\vec{H}=\vec{\nabla} \int_{V} \vec{J} \cdot \vec{\nabla}\left|\frac{1}{\vec{r}-\vec{r}_{0}}\right| d^{3} r_{0} .
$$

Assuming that the direction of magnetization is the same throughout the volume $V r$, then

$$
\vec{J} \cdot \vec{\nabla}=J \frac{d}{d r} .
$$

Putting (7) in (6) gives

$$
\vec{H}=\vec{\nabla} \frac{d}{d r} \int_{V} J\left|\frac{1}{\vec{r}-\vec{r}_{0}}\right| d^{3} r_{0} .
$$

Gauss, however, expresses the volume integral in terms of the surface integral given by

$$
\int_{V} \vec{V} \cdot \vec{F} d V=\int_{S} \vec{F} \cdot \widehat{n} d A .
$$

If the point $P$ is outside the volume, it implies that surface $S$ encloses no attractive mass, and then the right-hand side of (9) is zero. Hence

$$
\int_{V} \vec{\nabla} \cdot \vec{F} d^{3} r_{0}=0 .
$$

Differentiating (10), we have

$$
\vec{\nabla} \cdot \vec{F}=0 .
$$

Taking $\vec{H}$ as the function, the equation becomes

$$
\vec{\nabla} \cdot \vec{H}=0 .
$$

Putting (5) in (12), we have

$$
\begin{aligned}
\vec{\nabla} \cdot \vec{\nabla} \cdot A & =0 \\
\Longrightarrow & \vec{\nabla}^{2} \cdot A=0 \\
& \therefore \frac{\partial^{2} A}{\partial x^{2}}+\frac{\partial^{2} A}{\partial y^{2}}+\frac{\partial^{2} A}{\partial z^{2}}=0 .
\end{aligned}
$$


If $P$ is enclosed within the volume $V$, the magnetic potential $A$ becomes

$$
A=-\int_{V-V^{\prime}} \vec{J} \cdot \vec{\nabla}\left|\frac{1}{\vec{r}-\vec{r}_{0}}\right| d^{3} r_{0}-\int_{V^{\prime}} \vec{J} \cdot \vec{\nabla}\left|\frac{1}{\vec{r}-r_{0}}\right| d^{3} r_{0} .
$$

The first term is nonsingular; therefore it is harmonic everywhere. $J$ may be made constant by making $A$ small enough in the second term:

$$
\vec{\nabla}^{2} \cdot A=-\int_{V^{\prime}} \vec{\nabla} \cdot \vec{J} \cdot \vec{\nabla} \cdot \vec{\nabla}\left|\frac{1}{\vec{r}-\vec{r}_{0}}\right| d^{3} r_{0}
$$

From Gauss theorem, (15) becomes

$$
\begin{aligned}
\vec{\nabla} \cdot A & =\int_{S} \vec{\nabla} \cdot \vec{J} \cdot \widehat{n} \cdot \vec{\nabla}\left|\frac{1}{\vec{r}-\vec{r}_{0}}\right| d^{3} r_{0} \\
& =-\vec{\nabla} \cdot \vec{J} \int_{S} \frac{\partial}{\partial r} \cdot \frac{1}{r} d^{3} r_{0} \\
& =-\vec{\nabla} \cdot \vec{J}\left(-\left(\frac{1}{r}\right)^{2}\right) \int_{S} d^{2} r_{0} \\
& =-\vec{\nabla} \cdot \vec{J}\left(-\left(\frac{1}{r}\right)^{2}\right) 4 \pi\left(r^{\prime \prime}\right)^{2} \\
& =-\vec{\nabla} \cdot \vec{J} \cdot \frac{4 \pi\left(r^{\prime}\right)^{2}}{\left(r^{\prime}\right)^{2}} \\
\vec{\nabla} \cdot A & =4 \pi \vec{\nabla} \cdot \vec{J} .
\end{aligned}
$$

Equation (17) is the potential equation within regions occupied by magnetic bodies.

Magnetic properties of different types of soil display different aspects of soil mineralogy. The minerals that are present in soil are either natural (through lithogenesis, pedogenesis) or of anthropogenic origin (industrial residues). The magnetic mineral content of the soil can be expressed in very broad terms by its magnetic susceptibility [28]. Magnetic susceptibility is a measure of iron-bearing components in a material and it can be used to identify the type of the material on which the test is conducted as well as the amount of the iron-bearing minerals that the material contains. The determination of magnetic susceptibility can be a useful, sensitive, and fast method which provides an important parameter used in mineralogy and granulometry.

3.2. Peter's Half-Slope Method. A theoretically based graphical method was devised by [29] and is known as Peter's halfslope method (Figure 3). In his classical paper on magnetic interpretation, he presented a rule of thumb to find the depth to the magnetic source. Peter's rule is based on the mathematical expression for magnetic anomalies over vertical dikes with vertical polarization.

In Figure 3 a tangent (line 1) is drawn to the point of maximum slope and, using a right-angled triangle construction, a line (line 2) with half the slope of the original tangent is then constructed. Two further lines with the same shape as line 2 are then drawn where they form tangents to the anomaly (lines 3 and 4). The horizontal distance, $d$, between these

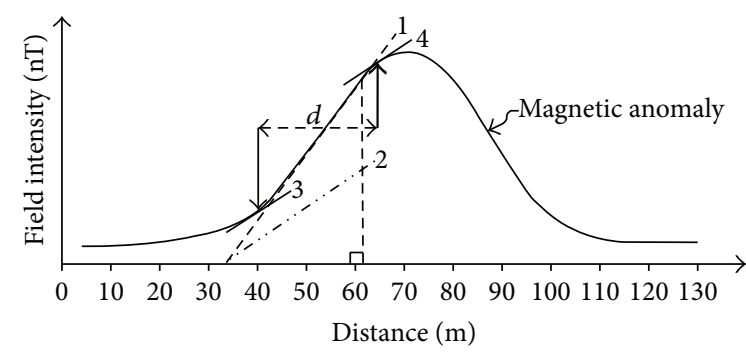

Figure 3: Peter's half-slope method of depth-to-basement determination.

two tangents is a measure of the depth to the magnetic body. According to Peter, the half-maximum slope distance $(d)$ is equal (approximately) to $1.6 \mathrm{~h}$, where $\mathrm{h}$ is the depth to the magnetic source (Figure 3). Assign the magnetic body an index value or "proportionality factor," ranging from 1.2 to 2 , depending on the object's size. For example, large objects would have a value approaching 2, while a smaller item, such as a handgun, would be around 1.2. There is no formula to assign specific index values to objects of certain sizes, so the value depends on your perception of the object's size, with the typical index value at 1.6. Divide distance by index value to find the depth of the object. The depth will be in feet, meters, or kilometers, depending on the unit of distance. If you are not aware of the object's size, divide the distance by both 1.2 and 2 to determine the depths between which the object is buried. For bodies having very small width-to-depth ratios (i.e., thin sheets), $d=1.2 \mathrm{~h}$ and for bodies having very large width-to-depth ratios, $d=2.0 \mathrm{~h}$. Therefore, for a $2 \mathrm{D}$ body with vertical sides, uniform and nearly vertical magnetization, the following holds: $d=1.2 \mathrm{~h}$ (very thin body), $d=1.6 \mathrm{~h}$ (intermediate thickness), and $d=2.0 \mathrm{~h}$ (very thick body), where $d$ is the horizontal distance corresponding to half the maximum slope, that is tangent to the curve, and $h$ is depth to the basement of the body [29].

3.3. Resistivity Method. Conrad Schlumberger first used resistivity method in 1912 [30]. Electrical methods comprise a multiplicity of separate techniques that employ differing instruments and procedures, have variable exploration depth and lateral resolution, and are known by a large lexicon of names and acronyms describing techniques and their variants. Electrical methods can be described in four classes: direct current resistivity, electromagnetic, induced polarization, and self-potential.

In spite of all the variants, measurements fundamentally are of the earth's electrical impedance or relate to changes in impedance. Electrical methods have broad application to mineral and environmental problems: they may be used to identify sulfide minerals, are directly applicable to hydrologic investigations, and can be used to identify structures and lithologies [7].

In resistivity surveying, information about the subsurface distribution of electrical conductivity is obtained by examining how currents flow in the earth [31]. Direct current (DC) resistivity methods involve injecting a steady state 


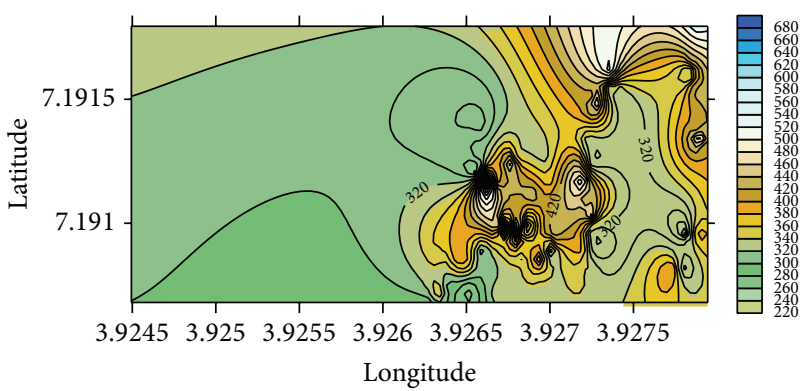

Figure 4: 2D contour map of the study area.
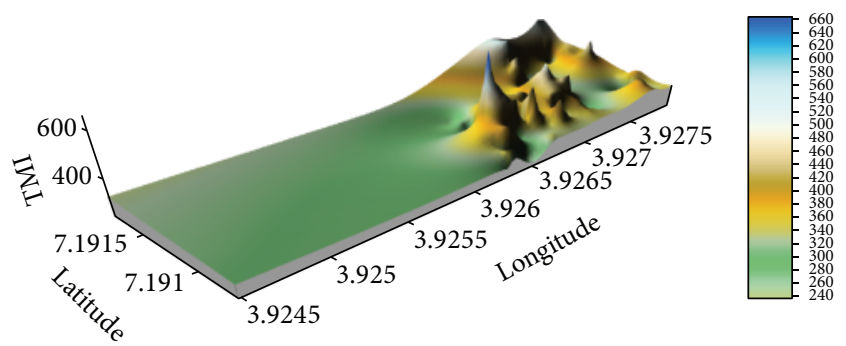

Figure 5: 3D contour map of the study area.

electrical current into the ground and observing the resulting distribution of potentials (voltages) at the surface or within boreholes. Like all geophysical processes, DC surveys can be described in terms of input energy, the earth's physical properties, and signals or data that are measured $[2,26]$.

Table 1 shows some minerals' electrical conductivity and magnetic susceptibility ranges.

\section{Methodology}

This study focused on the subsurface geological structures based on the qualitative interpretations of both resistivity and magnetic data collected from surveys carried out. The reason for using these methods is to be able to delineate the depths and regions of high and low concentration of beryl, mica, feldspar, tourmaline, columbite, and tantalite which were found in grains scattered on the ground surface; larger samples excavated by artisan miners were also found around the study area. The angles of declination and inclination of the locality are $-2.38^{\circ}$ and $-11.68^{\circ}$, respectively.

4.1. Magnetometry and Resistivity Surveys. The surveys commenced with the assessment of the site; we avoided high tension transmission lines and grounded metallic structures such as metal fences, pipelines, and other sources that could generate noise to the data.

The magnetic measurements were performed in 10 profiles using a G-816 proton precession magnetometer with $10 \mathrm{~m}$ spacing in between each profiles and $10 \mathrm{~m}$ stations interval. There are some obstructions such as pits drilled by the artisan miners; these pits prevented us from carrying out no more than four to five measurements in some profiles, such as profiles 5, 6, and 9. A total of 80 data points were obtained

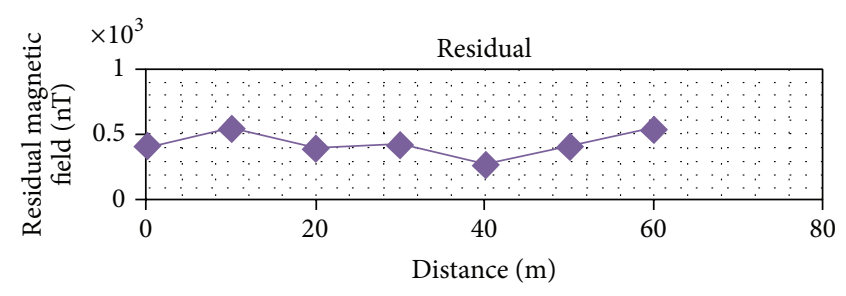

Figure 6: Profile 1.

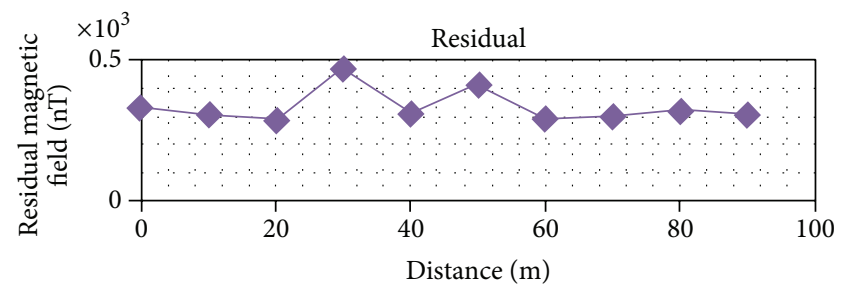

Figure 7: Profile 2.

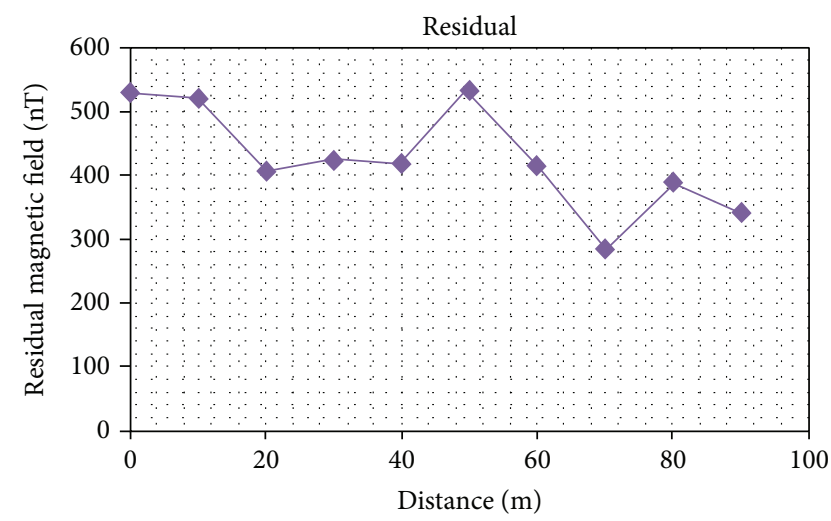

Figure 8: Profile 3.

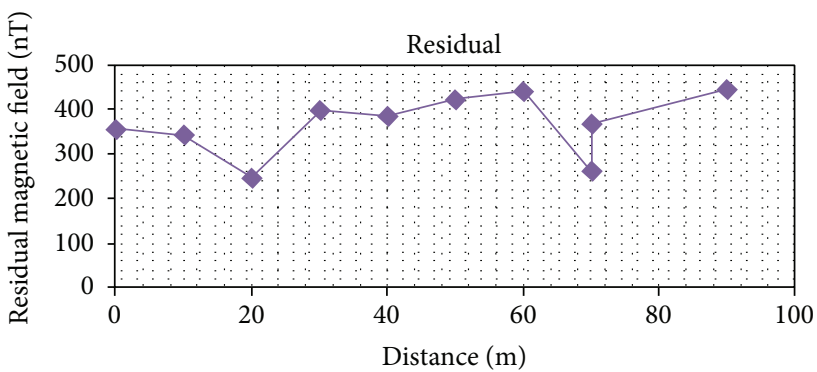

Figure 9: Profile 4.

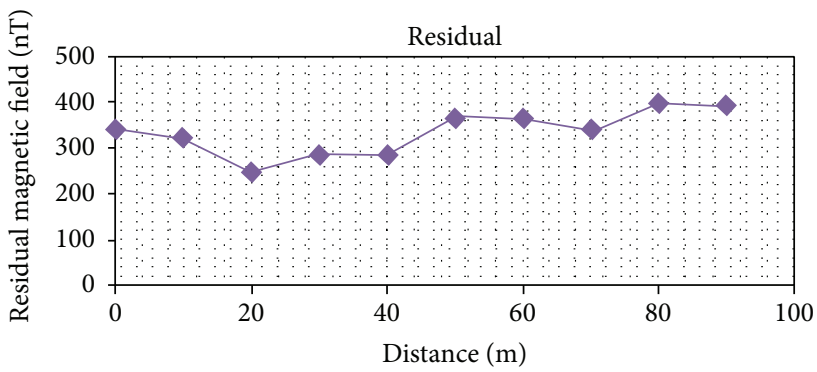

Figure 10: Profile 7. 
TABLE 1: Common minerals electrical conductivity and magnetic susceptibility values [26].

\begin{tabular}{|c|c|c|c|c|}
\hline Minerals & Susceptibility mean, IU & Susceptibility range, IU & Conductivity mean, $\mathrm{Sm}^{-1}$ & Conductivity range, $\mathrm{Sm}^{-1}$ \\
\hline Pyrrhotite & 1.5 & $0.006-1.6$ & 104 & $20.0-1.5 \times 10^{5}$ \\
\hline Ilmenite & 1.9 & $0.3-3.8$ & & $20.0 \times 10^{-2}-1.0 \times 10^{3}$ \\
\hline Magnetite & 6.3 & $5.0 \times 10^{-6}-5.7 \times 10^{3}$ & & $1.8 \times 10^{-4}-2.0 \times 10^{5}$ \\
\hline Pyrite & 0.0015 & & 3.3 & \\
\hline
\end{tabular}

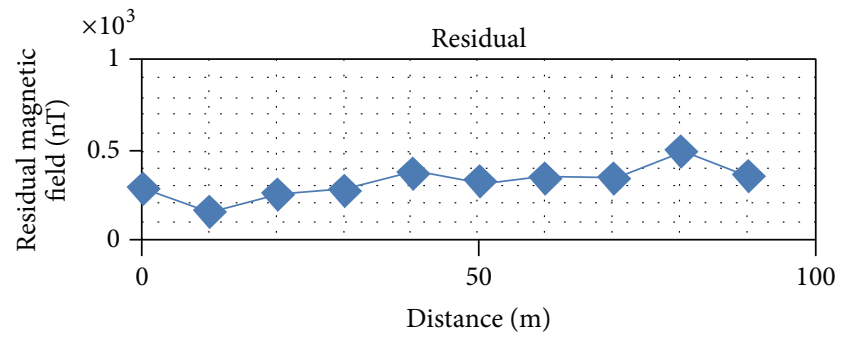

FIgURE 11: Profile 8.

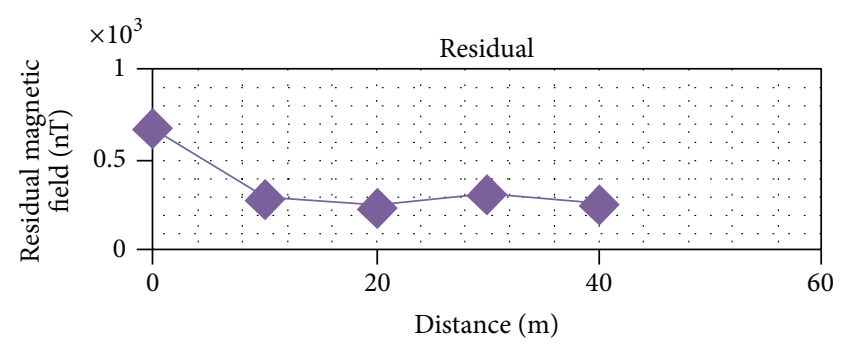

Figure 12: Profile 9.

from the study area. The coordinates of each station points were recorded by GPS. A base station was set up around 200 meters away from the survey area where magnetic readings were taken at 60-minute time interval to remove the diurnal variation effects of the earth's magnetic field from the data. While the data acquisition procedures were well performed, it was still not practical to make all the readings needed to clearly process data. First step in magnetic processing was inspecting raw data for spikes, gaps, instrument noise, or any other irregularities in the data. The next step involved diurnal variation correction and IGRF correction. Once corrections were done, the data were exported into a grid file to the program Surfer 10. After calculating a grid from XYZ data in Surfer, residual was carried out to compute the difference between a grid value and the raw data at any definite location of the site. The raw magnetic data obtained were plotted as 2D and 3D magnetic contour maps using Surfer 10 (Figures 4 and 5). Also, the residual anomalies obtained were plotted against distance using Microsoft Excel (Figures 6-13), and Peter's half-slope method was used to find the depth to the magnetic sources.

Resistivity data were acquired using Campus Tiger resistivity meter; the choice of this equipment was based on the fact that it has the capacity to transmit signals to a very deep depth of the subsurface. Schlumberger configuration was used and a total of nine (9) vertical electrical soundings

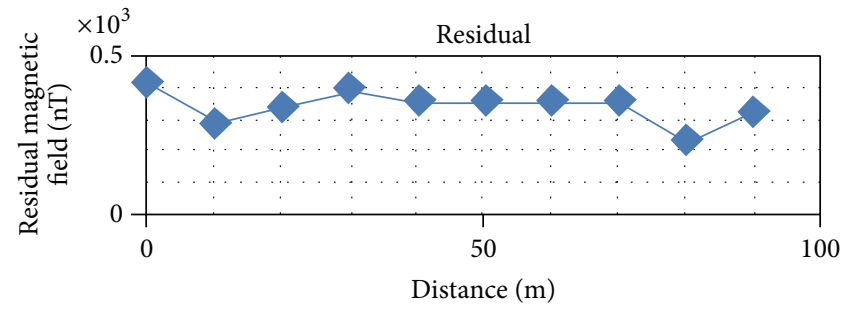

Figure 13: Profile 10.

(VESs) were carried out on the study area. All vertical electrical soundings were $150 \mathrm{~m}$ long, $75 \mathrm{~m}$ on each side of the referenced points which were $10 \mathrm{~m}$ apart. Partial and complete curve matching were used to interpret the apparent resistivity data obtained and sounding curves were generated (Figures 14-21).

\section{Results and Discussion}

5.1. Magnetic Survey Result. There are several methods of presenting magnetic data $[4,10,12]$, but only two methods, contour map and profile, were adopted in this study.

5.1.1. Contour Maps. These are grid-based presentation used to produce scaled $2 \mathrm{D}$ and $3 \mathrm{D}$ contour maps of the subsurface (Figures 4 and 5).

A visual inspection of the contour maps (Figures 4 and 5) shows that the contour lines of the western part of the contour map are widely spaced indicating that the depth to magnetic basement in these areas is relatively large or that is no presence of pegmatite whereas, at the eastern part of the contour map, the contour lines are closely spaced indicating that the depth to the basement is shallow in these areas. The closely spaced, linear subparallel orientation of contours at the eastern part suggests shallow subsurface geologic structures and the possibility of faults or local fractured zones passing through these areas. This further confirms the earlier submission of [3]. Also, there are spikes at the eastern part indicating that there is presence of magnetic mineral rocks, whereas the western part is plain and there are no spikes at all indicating that there is a little or no presence of magnetic mineral rocks.

On the basis of the variation in magnetic intensity across the study area, there was a high magnetic intensity at the eastern region and low magnetic intensity at the western region of the contour maps. The magnetic signature obtained for the total component relative magnetic intensity plot along the traverses showed considerable varying amplitude from 
TABle 2: Summary of depth estimates from the ground magnetic data.

\begin{tabular}{|c|c|c|c|c|}
\hline Profiles & $\begin{array}{l}\text { Very thin body } \\
(\mathrm{m})\end{array}$ & $\begin{array}{l}\text { Intermediate thickness } \\
(\mathrm{m})\end{array}$ & $\begin{array}{l}\text { Very thick body } \\
(\mathrm{m})\end{array}$ & $\begin{array}{l}\text { Average } \\
(\mathrm{m})\end{array}$ \\
\hline 1 & 8.58 & 6.44 & 5.15 & 6.72 \\
\hline \multirow{2}{*}{2} & 9.17 & 6.88 & 5.50 & 7.18 \\
\hline & 8.25 & 6.19 & 4.95 & 6.46 \\
\hline 3 & 7.40 & 5.55 & 4.44 & 5.80 \\
\hline 4 & 8.12 & 6.09 & 4.87 & 6.36 \\
\hline 5 & 7.75 & 5.81 & 4.65 & 6.07 \\
\hline 7 & 7.94 & 5.95 & 4.77 & 6.22 \\
\hline \multirow{2}{*}{8} & 8.13 & 6.10 & 4.88 & 6.37 \\
\hline & 7.45 & 5.59 & 4.47 & 5.84 \\
\hline 9 & 7.98 & 5.99 & 4.79 & 6.25 \\
\hline 10 & 8.13 & 6.10 & 4.88 & 6.37 \\
\hline Mean & 8.08 & 6.06 & 4.85 & 6.33 \\
\hline Standard deviation & 0.50 & 0.37 & 0.30 & 0.39 \\
\hline
\end{tabular}

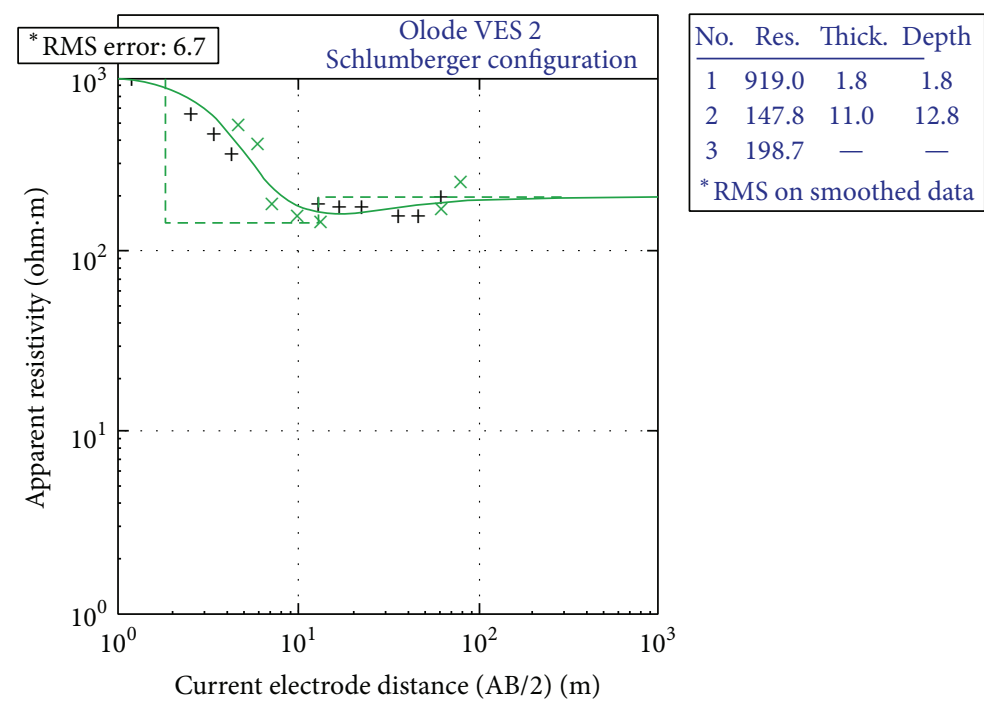

FIGURE 14: Sounding curve of VES 2.

a minimum peak value of about $155.3 \mathrm{nT}$ at a depth of about $6.37 \mathrm{~m}$ to a maximum peak value of about $670.3 \mathrm{nT}$ at a depth of about $6.25 \mathrm{~m}$. The depth of the magnetic basement reveals the major and minor rock contacts in the area separated with different colours (Figure 5). The eastern part towards the center area supports the previous reports on the existence of geological structures (such as mica, feldspar, beryl, tantalite, tourmaline, and columbite) in this part of the Ibadan schist belt $[15,23]$.

5.1.2. Profiles. This method is the oldest form of data presentation and it has the advantage of being able to show details that cannot be shown in grid-based presentations. The ground magnetic profiles of the study area were generated using Microsoft Excel as shown in Figures 6 to 13. From these figures, the depth estimation of the basement in the area and identification of the rock boundaries was carried out using Peter's half-slope method [29]. The estimate depth calculations for profiles 1 and 2 are shown in Figures 6 and 7 . Estimated depths calculated for profiles 3 to 10 (Figures 8, 9, $10,11,12$, and 13) are shown in Table 2.

In profile 1 in Figure 6, the estimated depth was deduced using Peter's half-slope method as follows:

200 units represents $1 \mathrm{~cm}$ along "residual magnetic field" axis while 20 units represents $1 \mathrm{~cm}$ on "distance" axis.

By using a centimeter rule, along the "distance" axis on the graph in Figure 6, $13.2 \mathrm{~cm}=80 \mathrm{~m}$ :

$$
\begin{aligned}
& 13.2 \mathrm{~cm}=80 \mathrm{~m} \\
& 1 \mathrm{~cm}=x \\
& \Longrightarrow x=1 \mathrm{~cm}=6.06 \mathrm{~m} .
\end{aligned}
$$




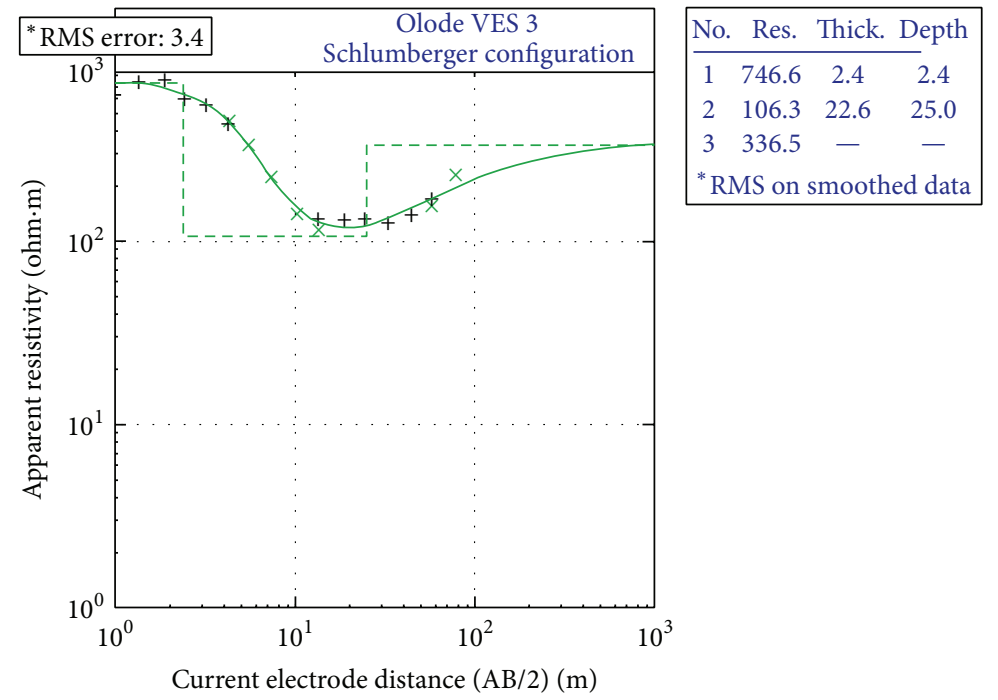

FIGURE 15: Sounding curve of VES 3.

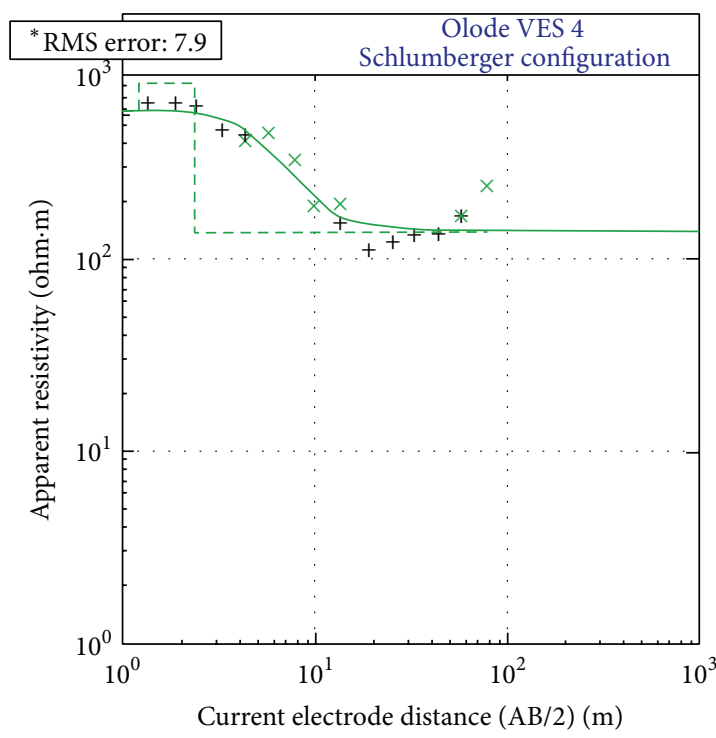

\begin{tabular}{|cccc}
\hline No. & Res. & Thick. & Depth \\
\hline 1 & 584.6 & 1.2 & 1.2 \\
2 & 829.3 & 1.2 & 2.4 \\
3 & 140.9 & - & - \\
* RMS on & smoothed data \\
\hline
\end{tabular}

*RMS on smoothed data

FIGURE 16: Sounding curve of VES 4.

The horizontal distance between the two tangents is $d=$ $1.7 \mathrm{~cm}$.

Therefore,

$$
d=1.7 \times 6.06=10.30 \mathrm{~m} .
$$

For very thin body, $d=1.2 \mathrm{~h}$ :

$$
\text { Depth, } h=\frac{10.30}{1.2}=8.58 \mathrm{~m} \text {. }
$$

For intermediate thickness, $d=1.6 \mathrm{~h}$ :

$$
\text { Depth, } h=\frac{10.30}{1.6}=6.44 \mathrm{~m} \text {. }
$$

For very thick body, $d=2.0 \mathrm{~h}$ :

$$
\text { Depth, } h=\frac{10.30}{2.0}=5.15 \mathrm{~m} \text {. }
$$

In profile 2 in Figure 7 we have the following:

For the first peak on the graph (Figure 7),

100 units represents $1 \mathrm{~cm}$ along "residual magnetic field" axis while 20 units represents $1 \mathrm{~cm}$ on "distance" axis.

By using a centimeter rule along the "distance" axis on the graph in Figure 7,

$$
\begin{aligned}
& 9 \mathrm{~cm}=100 \mathrm{~m} \\
& 1 \mathrm{~cm}=x \\
& \Longrightarrow x=1 \mathrm{~cm}=11 \mathrm{~m} .
\end{aligned}
$$

The horizontal distance, $d$, between the two tangents is $1 \mathrm{~cm}$. 


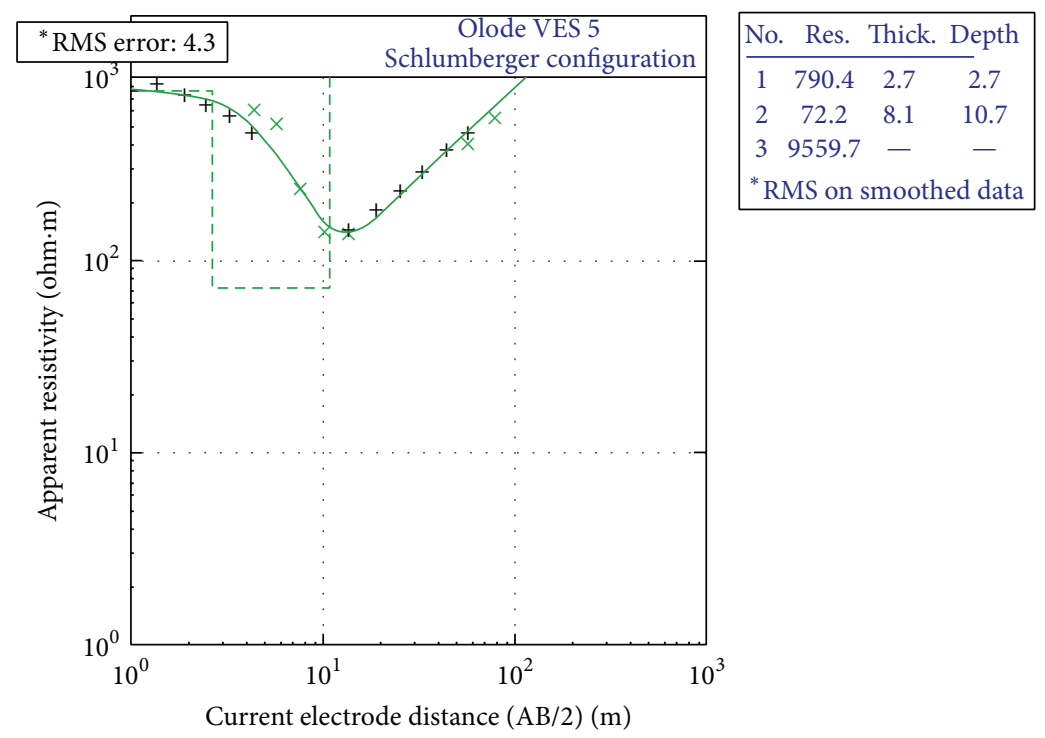

FIGURE 17: Sounding curve of VES 5.

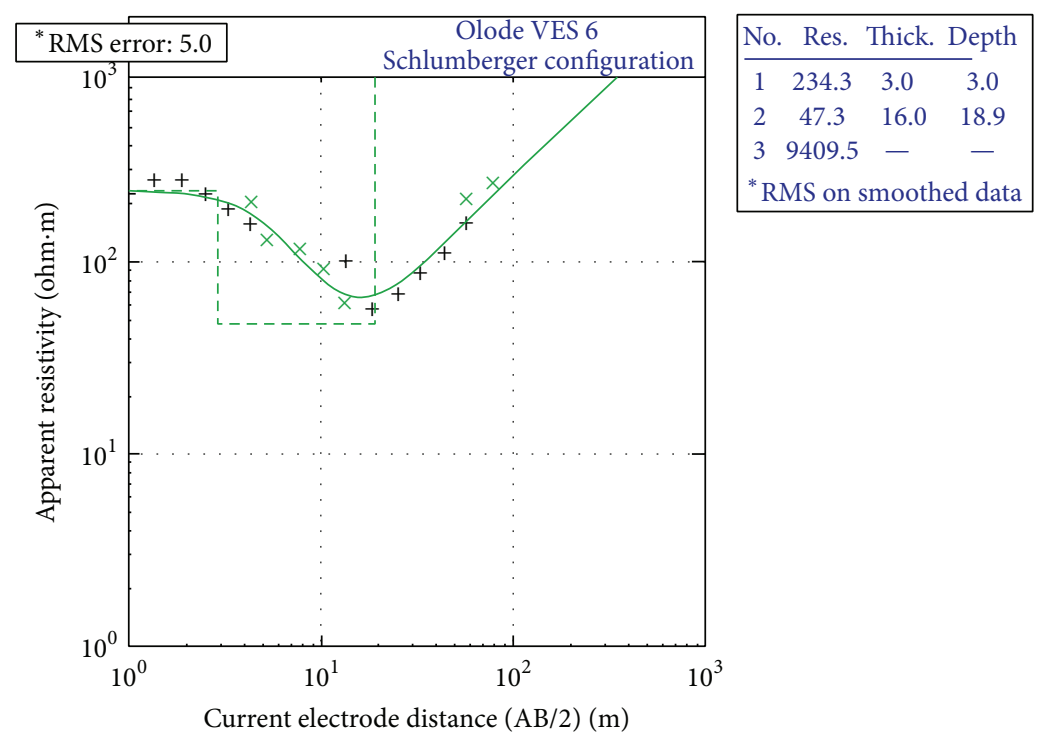

FIGURE 18: Sounding curve of VES 6.

Therefore, $d=11 \mathrm{~m}$.

For very thin body, $d=1.2 \mathrm{~h}$ :

$$
h=\frac{11}{1.2}=9.17 \mathrm{~m} .
$$

For intermediate thickness, $d=1.6 \mathrm{~h}$ :

$$
h=\frac{11}{1.6}=6.88 \mathrm{~m} \text {. }
$$

For very thick body, $d=2.0 \mathrm{~h}$ :

$$
h=\frac{11}{2.0}=5.50 \mathrm{~m} .
$$

For the second peak on the graph (Figure 7),

$$
x=11 \mathrm{~m} .
$$

The horizontal distance, $d$, between the two tangents is $0.9 \mathrm{~cm}$.

Therefore, $d=9.9 \mathrm{~m}$.

For very thin body, $d=1.2 \mathrm{~h}$ :

$$
h=\frac{9.9}{1.2}=8.25 \mathrm{~m} \text {. }
$$

For intermediate thickness, $d=1.6 \mathrm{~h}$ :

$$
h=\frac{9.9}{1.6}=6.19 \mathrm{~m} \text {. }
$$


TABLE 3: Summary of sounding curves.

\begin{tabular}{|c|c|c|c|c|c|c|}
\hline VES & Layers & $\begin{array}{c}\text { Resistivity } \\
(\mathrm{ohm} \cdot \mathrm{m})\end{array}$ & $\begin{array}{l}\text { Depth } \\
(\mathrm{m})\end{array}$ & $\begin{array}{l}\text { Thickness } \\
(\mathrm{m})\end{array}$ & Possible rocks & Curve types \\
\hline \multirow{3}{*}{1} & 1 & 746.4 & 1.3 & 1.3 & $\begin{array}{l}\text { Sand stone, clay, magnetite ore, and } \\
\text { limestone }\end{array}$ & \multirow{3}{*}{$\mathrm{H}$} \\
\hline & 2 & 165.2 & 2.6 & 1.3 & Magnetite ore, limestone & \\
\hline & 3 & 174.3 & & & Magnetite ore, limestone & \\
\hline \multirow{3}{*}{2} & 1 & 919.0 & 1.8 & 1.8 & $\begin{array}{c}\text { Sand stone, magnetite ore, schists, and } \\
\text { shale }\end{array}$ & \multirow{3}{*}{$\mathrm{H}$} \\
\hline & 2 & 147.8 & 12.8 & 11.0 & Magnetite ore, limestone & \\
\hline & 3 & 198.7 & & & Magnetite ore, limestone & \\
\hline \multirow{3}{*}{3} & 1 & 746.6 & 2.4 & 2.4 & $\begin{array}{l}\text { Sand stone, clay, magnetite ore, and } \\
\text { limestone }\end{array}$ & \multirow{3}{*}{$\mathrm{H}$} \\
\hline & 2 & 106.3 & 25.0 & 22.6 & Magnetite ore, limestone & \\
\hline & 3 & 336.5 & & & Sand stone, magnetite ore, and limestone & \\
\hline \multirow{3}{*}{4} & 1 & 584.6 & 1.2 & 1.2 & Sand stone, magnetite ore, and limestone & \multirow{3}{*}{$\mathrm{K}$} \\
\hline & 2 & 829.3 & 2.4 & 1.2 & $\begin{array}{c}\text { Sand stone, clay, magnetite ore, and } \\
\text { limestone }\end{array}$ & \\
\hline & 3 & 140.9 & & & Magnetite ore, limestone & \\
\hline \multirow{3}{*}{5} & 1 & 790.4 & 2.7 & 2.7 & $\begin{array}{l}\text { Sand stone, clay, magnetite ore, and } \\
\text { limestone }\end{array}$ & \multirow{3}{*}{$\mathrm{H}$} \\
\hline & 2 & 72.2 & 10.7 & 8.1 & Sand stone, magnetite ore, and clay & \\
\hline & 3 & 9559.7 & & & Quartzite, anthracite, and slate & \\
\hline \multirow{3}{*}{6} & 1 & 234.3 & 3.0 & 3.0 & Magnetite ore, sandstone & \multirow{3}{*}{$\mathrm{H}$} \\
\hline & 2 & 47.3 & 18.9 & 16.0 & Sand stone, magnetite ore, and clay & \\
\hline & 3 & 9409.5 & & & Quartzite, anthracite, and slate & \\
\hline \multirow{4}{*}{7} & 1 & 138.2 & 0.6 & 0.6 & Magnetite ore, limestone & \multirow{4}{*}{ HA } \\
\hline & 2 & 28.6 & 2.3 & 1.7 & Sand stone, magnetite ore, and clay & \\
\hline & 3 & 57.1 & 26.5 & 24.2 & Sand stone, magnetite ore, and clay & \\
\hline & 4 & 234.4 & & & Magnetite ore, sandstone & \\
\hline \multirow{3}{*}{8} & 1 & 144.8 & 1.5 & 1.5 & $\begin{array}{l}\text { Limestone, sand stone, clay, magnetite } \\
\text { ore, and quartzite }\end{array}$ & \multirow{3}{*}{$\mathrm{H}$} \\
\hline & 2 & 38.5 & 20.1 & 18.7 & Sand stone, clay, and magnetite ore & \\
\hline & 3 & 1275.3 & & & Limestone, sand stone, and quartzite & \\
\hline \multirow{3}{*}{9} & 1 & 109.8 & 2.9 & 2.9 & Sand stone, clay, and magnetite ore & \multirow{3}{*}{$\mathrm{H}$} \\
\hline & 2 & 26.9 & 11.5 & 8.6 & Limestone, sand stone, and magnetite ore & \\
\hline & 3 & 368.9 & & & Sand stone, magnetite ore, and limestone & \\
\hline
\end{tabular}

For very thick body, $d=2.0 \mathrm{~h}$ :

$$
h=\frac{9.9}{2.0}=4.95 \mathrm{~m} \text {. }
$$

Table 2 summarizes the estimated depths derived from profiles 1 to 10 .

From Table 2, mineral rocks with very thin, intermediate, and very thick bodies have their depths ranges as $8.08 \pm$ $0.50 \mathrm{~m}, 6.06 \pm 0.37 \mathrm{~m}$, and $4.85 \pm 0.30 \mathrm{~m}$, respectively. On the average, the depths of these mineral rocks from the surface are in the interval of $5.80 \mathrm{~m}$ to $6.72 \mathrm{~m}$. Based on this method, Peter does not specify the shape of the buried body. He assumes that there can be a deformation of these mineral rocks due to factors such as weathering. He gives the possible geometry of the mineral rocks through the index values or proportionality factor. The shallower the depth, the thicker the body of the mineral rocks and the anomaly will be more pronounced. Also, the deeper the depth, the thinner the body of the mineral rocks and the anomaly will be less pronounced.

5.2. Resistivity Survey Result. The conductivities of mineral rocks in the study area were investigated and nine vertical electrical soundings were taken with $10 \mathrm{~m}$ interval from each of the reference points. The resulting plots (sounding curves) obtained are shown in Figures 14-21.

Table 3 summarizes the apparent resistivity values in each of the sounding curves and gives possible rocks in each layer of the vertical electrical soundings (VESs).

The soundings curves are H type in VESs 2 and 3 (Figures 14 and 15);VES 4 (Figure 16) gives K-type curve and shows 


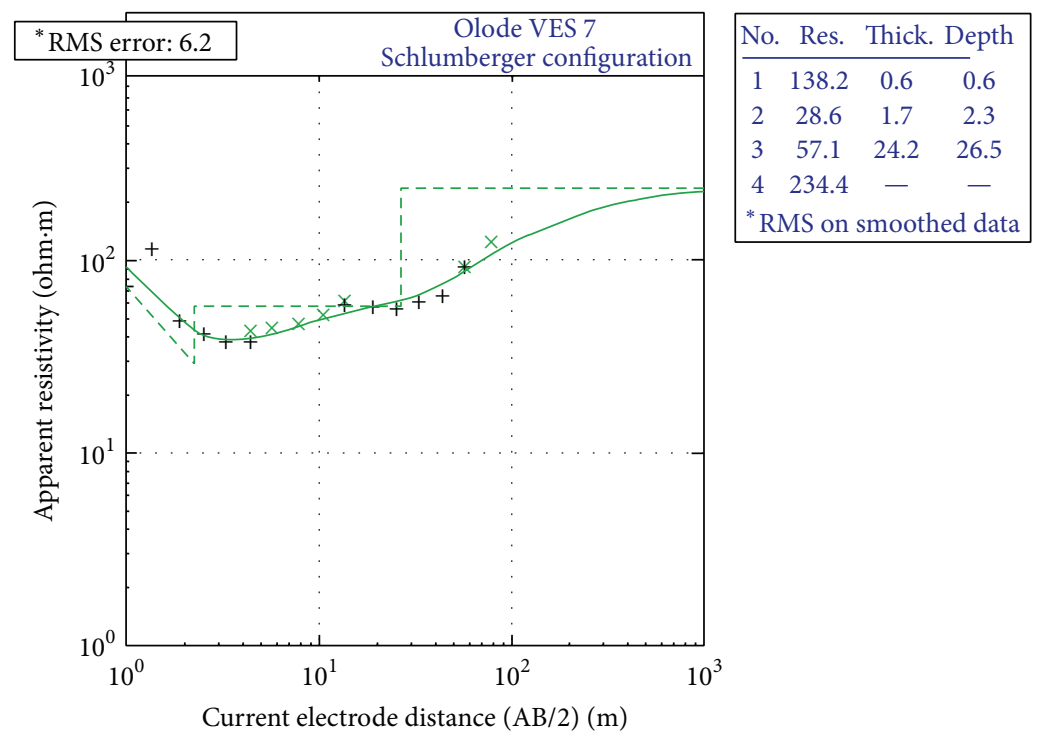

FIGURE 19: Sounding curve of VES 7.

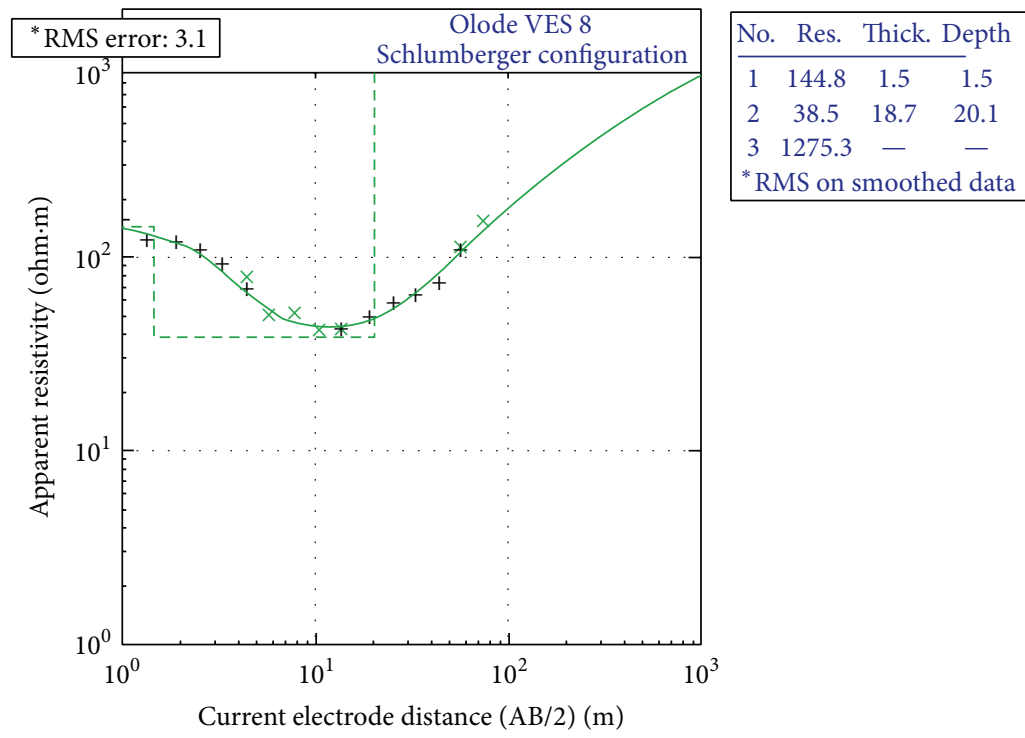

FIGURE 20: Sounding curve of VES 8.

that complex basements are not very close to the surface of the earth. In VESs 5, 6, 8, and 9 (Figures 17, 18, 19, and 20), the curves are $\mathrm{H}$ type. VES 7 has 4 layers and the sounding curve is HA type. This implies that most minerals in the study area contain magnetite ore which is a black magnetic mineral consisting of iron oxide and it is highly conductive. It has a resistivity range between $0.1 \mathrm{ohm} \cdot \mathrm{m}$ and $1000 \mathrm{ohm} \cdot \mathrm{m}$ (Table 1). This ore is present in rocks in VESs $1,2,3,4,7$, 8 , and 9; this affirms that there are some magnetic rocks or minerals in the areas where the VESs were taken. Rocks such as tantalite, beryl, mica, and gemstones are suspected to be in the study area (Table 3 ). The resistivity values of rocks and minerals revealed by VESs 1 to 9 were compared with published (standard) magnetic susceptibility of rocks and minerals. We deduced that VESs 1, 2, 3, 4, 7, 8, and 9 are underlined with rocks of relatively high conductivity and magnetic susceptibility values. VESs 5 and 6 show mineral rocks with low conductivity and magnetic susceptibility values (Tables 2 and 3 ).

\section{Conclusion}

Geomagnetic and geoelectric methods had been used to investigate the depth and location of some mineral rocks such as mica, feldspar, beryl, tantalite, tourmaline, and other gemstones in the study area. The results of the two geophysical methods were in agreement and the following conclusions 


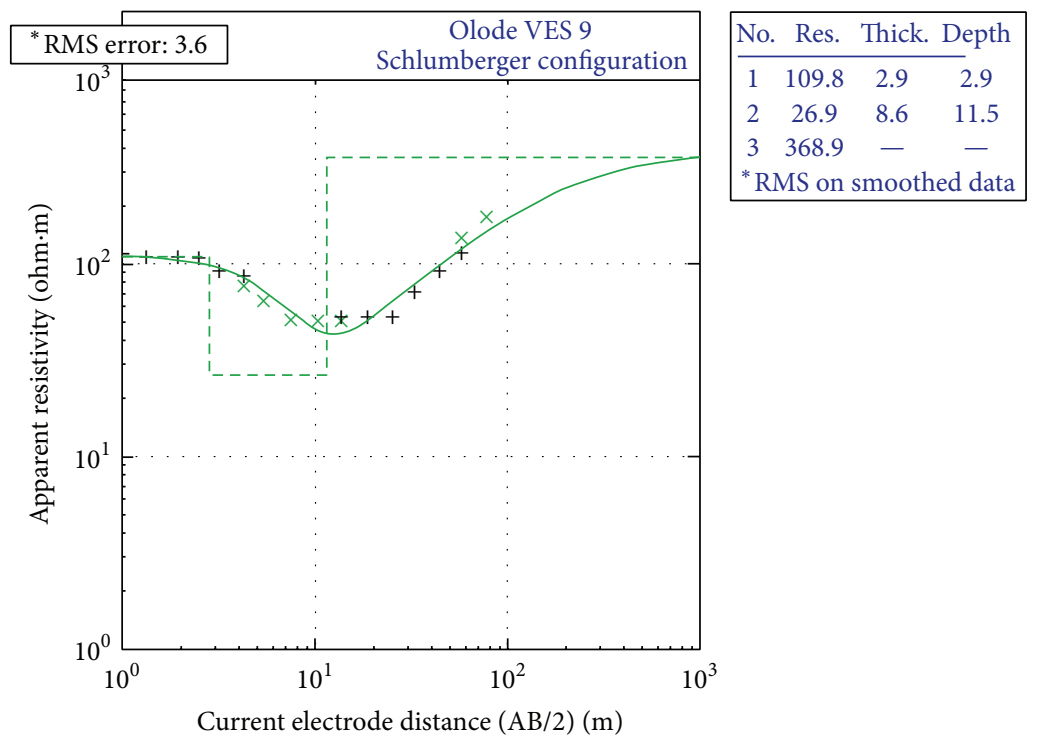

FIGURE 21: Sounding curve of VES 9.

could be made. There are rocks and minerals with high magnetic susceptibility and conductivity values from the center to the eastern regions of the study area and mineral rocks with low magnetic susceptibility and conductivity values at the western region of the study area. This conclusion affirms the earlier conclusions that the same minerals are responsible for both the conductivity and susceptibility of rocks [32]. The possible rocks in the region of high magnetic susceptibility and conductivity are columbite and tantalite while rocks in the region with low magnetic susceptibility and conductivity are sandstone, quartz, graphite, and feldspar. More than 50\% of the volume has an intermediate magnetic susceptibility values (Figure 5), indicating that the region is predominantly a pegmatite vein and that harboured rocks such as beryl, mica, and tourmaline exist in massive quantities. On the average, the depths of these mineral rocks from the surface fall in the interval of $5.80 \mathrm{~m}$ to $6.72 \mathrm{~m}$.

\section{Conflict of Interests}

The authors declare that there is no conflict of interests regarding the publication of this paper.

\section{References}

[1] K. Philip, M. Brooks, and L. Hill, An Introduction to Geophysical Exploration, Blackwell Science, London, UK, 3rd edition, 2002.

[2] W. Lowrie, Fundamentals of Geophysics, Cambridge University Press, Cambridge, UK, 2nd edition, 2011.

[3] J. S. Kayode, Ground magnetic study of Jeda-Iloko area, SouthWestern Nigeria and its geological implications [M.S. thesis], Federal University of Technology, Akure, Nigeria, 2006.

[4] O. Ojo Akintayo, "Geomagnetic and geoelectric investigation of mineral rocks at Awo, Osun State, southwest Nigeria," International Journal of Physical Research, vol. 1, no. 2, pp. 6074, 2013.
[5] K. S. Ishola, L. Adeoti, and A. Obianeri, "Interpretation of the historic site, Agorin in Badagry, Southwestern Nigeria using geophysical methods," Ozean Journal of applied Sciences, vol. 5, no. 1, pp. 85-99, 2010.

[6] J. S. Kayode and A. O. Adelusi, "Ground magnetic data interpretation of Ijebu-Jesa area, Southwestern Nigeria, using total component," Research Journal of Applied Sciences, Engineering and Technology, vol. 2, no. 8, pp. 703-709, 2010.

[7] A. Roy, "Depth of investigation in Wenner, three-electrode and dipole-dipole DC resistivity methods," Geophysical Prospecting, vol. 20, no. 2, pp. 329-340, 1972.

[8] S. L. Folami, "Interpretation of aeromagnetic anomalies in Iwaraja area, South Western Nigeria," Journal of Mining and Geology, vol. 28, no. 2, pp. 393-397, 1992.

[9] C. T. Young and D. R. Droege, "Archaeological applications of resistivity and magnetic methods at fort wilkins state park, michigan," Geophysics, vol. 51, no. 3, pp. 568-575, 1986.

[10] J. S. Kayode, P. Nyabese, and A. O. Adelusi, "Ground magnetic study of Ilesa east, Southwestern Nigeria," African Journal of Environmental Science and Technology, vol. 4, no. 3, pp. 122-131, 2010.

[11] R. Oni and B. Ebun, "Measurement and Interpretation of magnetic anomaly components in Low latitude," Journal of geophysical Research, vol. 74, no. 17, pp. 4233-4245, 1969.

[12] V. D. Obot and P. J. Wolfe, "Ground level magnetic study of Greene County Ohio," Ohio Journal of Science, vol. 80, pp. 50$54,1981$.

[13] M. N. Umego and S. B. Ojo, "A magnetic depth to basement analysis in the Sokoto basin, North Western Nigeria," Journal of Mining and Geology, vol. 31, no. 2, pp. 161-167, 1995.

[14] J. A. Adekoya, O. O. Kehinde-Phillips, and A. M. Odukoya, "Geological distribution of mineral resources in Southwestern Nigeria," in Prospects for Investment in Mineral Resources of Southwestern Nigeria, A. A. Elueze, Ed., pp. 1-13, Nigerian Mining and Geosciences (NMGS), 2003.

[15] T. R. Ajayi and O. Ogedengbe, "Opportunities for the exploitation of precious and rare metals in Nigeria," in Prospects for Investment in Mineral Resources of Southwestern Nigeria, A. 
A. Elueze, Ed., pp. 15-56, Nigerian Mining and Geosciences Society (NMGS), 2003.

[16] I. Garba, "Geochemical discriminaton of newly discovered raremetal bearing and barren pegmatites in the Pan-African (600 \pm $150 \mathrm{Ma}$ ) basement of northern Nigeria," Transactions of the Institution of Mining and Metallurgy B: Applied Earth Science, vol. 112, no. 3, pp. 287-292, 2003.

[17] O. A. Okunlola and O. Ogedengbe, "Investment potential of gemstone occurrences in Southwestern Nigeria," in Prospects for Investment in Mineral Resources of Southwestern Nigeria, A. A. Elueze, Ed., pp. 41-45, Nigerian Mining and Geosciences Society (NMGS), 2003.

[18] O. A. Okunlola, "Metallogeny of Tantalum-niobium mineralization of Precambrian pegmatite of Nigeria," Mineral Wealth, vol. 104, no. 2, pp. 38-50, 2005.

[19] O. A. Okunlola and S. Jimba, "Compositional trends in relation to $\mathrm{Ta}-\mathrm{Nb}$ mineralization in Precambrian pegmatites of Aramoko-Ara-Ijero area, Southwestern Nigeria," Journal of Mining and Geology, vol. 42, no. 2, pp. 113-126, 2006.

[20] O. A. Okunlola and B. E. Ofonime, "Geological setting, petrographical features and age of rare metal $(\mathrm{Ta}-\mathrm{Nb})$ mineralization of pegmatite of Komu area, Southwestern Nigeria," African Journal of Science and Technology, vol. 7, no. 1, pp. 96-110, 2006.

[21] O. A. Okunlola and E. B. Somorin, "Compositional features of Precambrian pegmatite of Itakpe area, Central Nigeria," Global Journal of Geological Science, vol. 4, no. 2, pp. 221-230, 2006.

[22] M. A. Rahaman, "Review of the Basement Geology of Southwestern Nigeria," in Geology of Nigeria, C. A. Kogbe, Ed., pp. 41-58, Elizabethan, Lagos, Nigeria, 1976.

[23] O. A. Okunlola, O. C. Adeigbe, and O. O. Oluwatoke, "Compositional and petrogenetic features of schistose rocks of ibadan area, Southwestern Nigeria," Earth Sciences Research Journal, vol. 13, no. 2, pp. 119-133, 2009.

[24] N. G. Obaje, Geology and Mineral Resources of Nigeria, vol. 120 of Lecture Notes in Earth Sciences, Springer, New York, NY, USA, 2009.

[25] L. L. Nettleton, Gravity and Magnetic in Oil Prospecting, McGraw-Hill, New York, NY, USA, 1976.

[26] W. M. Telford, L. P. Geldart, and R. E. Sheriff, Applied Geophysics, Cambridge University Press, Cambridge, UK, 3rd edition, 1990.

[27] D. S. Parasnis, Principles of Applied geophysics, Chapman \& Hall, New York, NY, USA, 3rd edition, 1978.

[28] R. Thompson and F. Oldfield, Environment Magnetism, Allen and Unwin, London, UK, 1986.

[29] L. J. Peters, "The direct approach to magnetic interpretation and its practical application," Geophysics, vol. 14, pp. 290-320, 1949.

[30] O. Koefoed, Geosounding Principles, 1, Elsevier Science, Amsterdam, The Netherlands, 1979.

[31] D. K. Butler, Near Surface Geophysics Textbook, vol. 13, Society of Exploration Geophysicis, 2005.

[32] R. C. Searle, "Magnetic susceptibility as a tool for investigating igneous rocks-experience from IODP Expedition 304," Scientific Drilling, no. 6, pp. 52-54, 2008. 

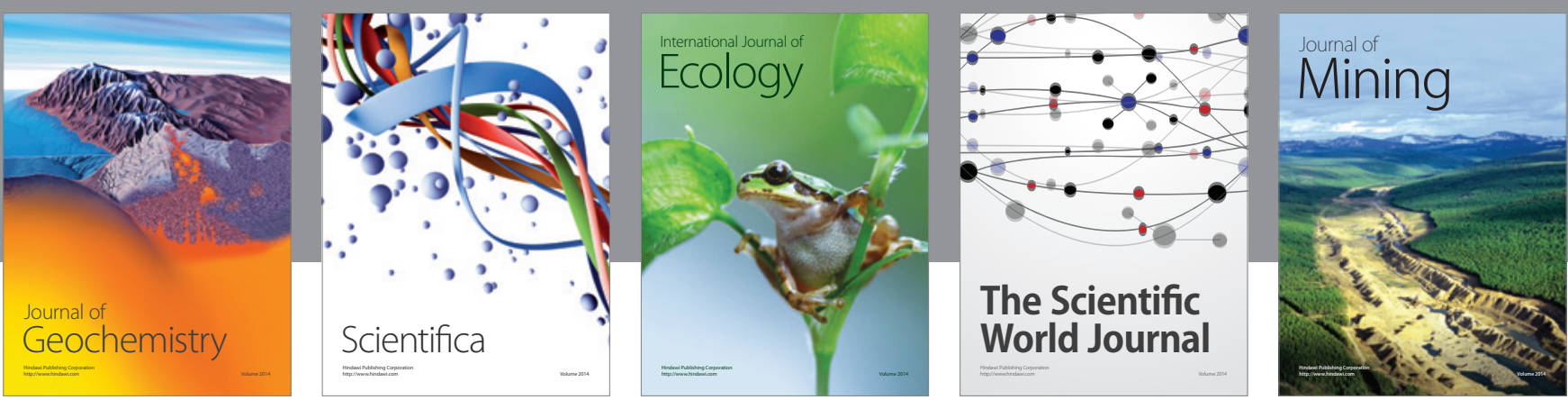

The Scientific World Journal
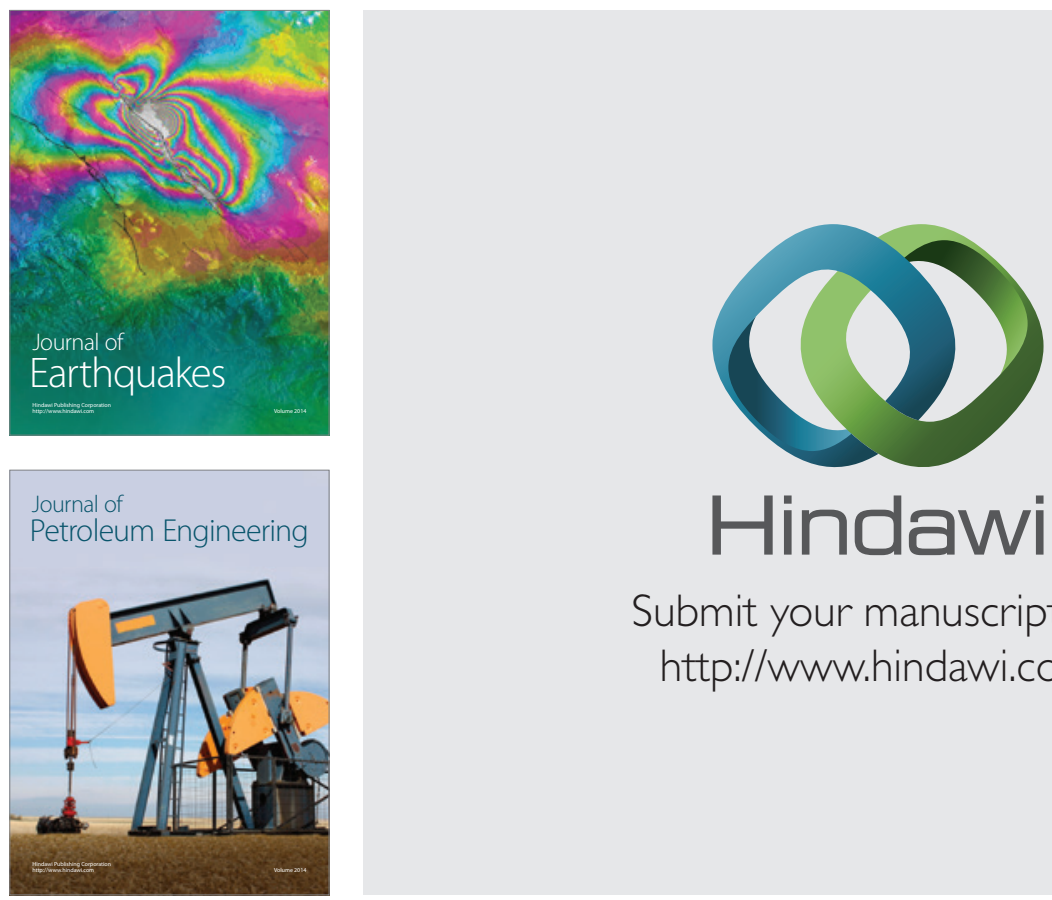

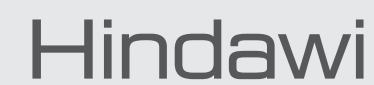

Submit your manuscripts at

http://www.hindawi.com
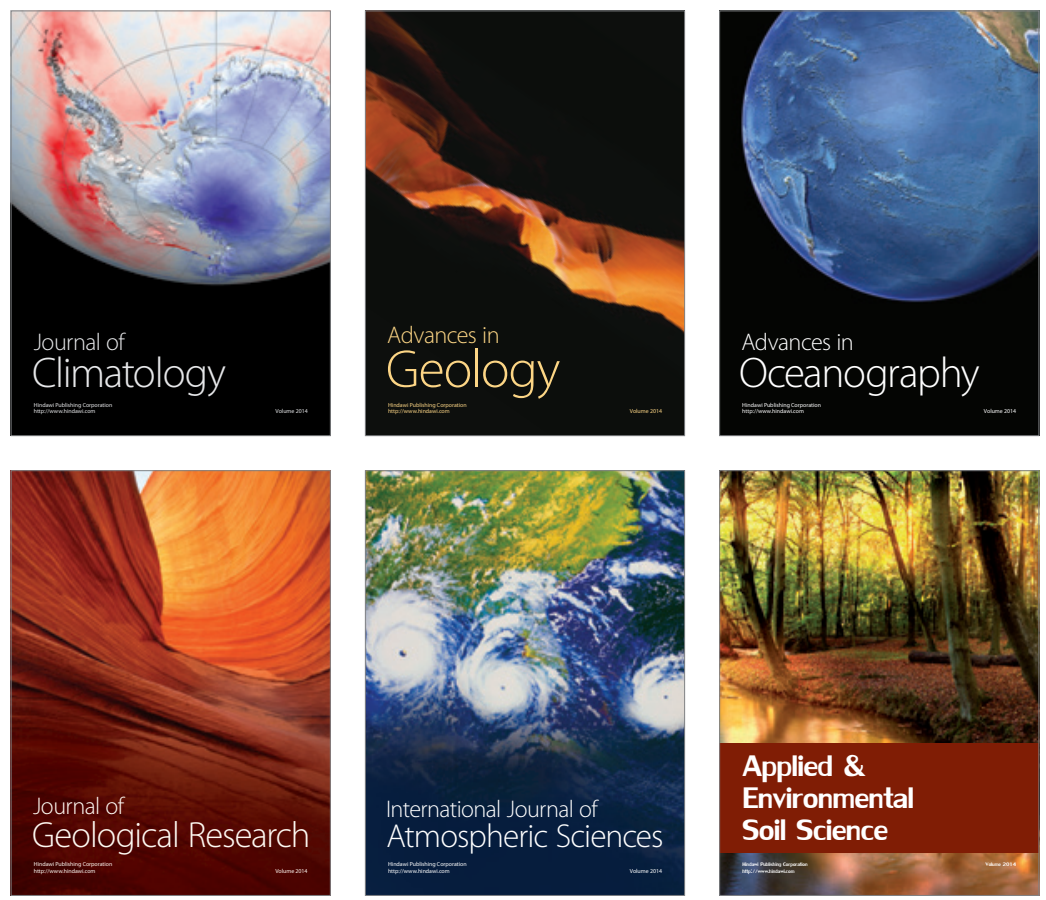
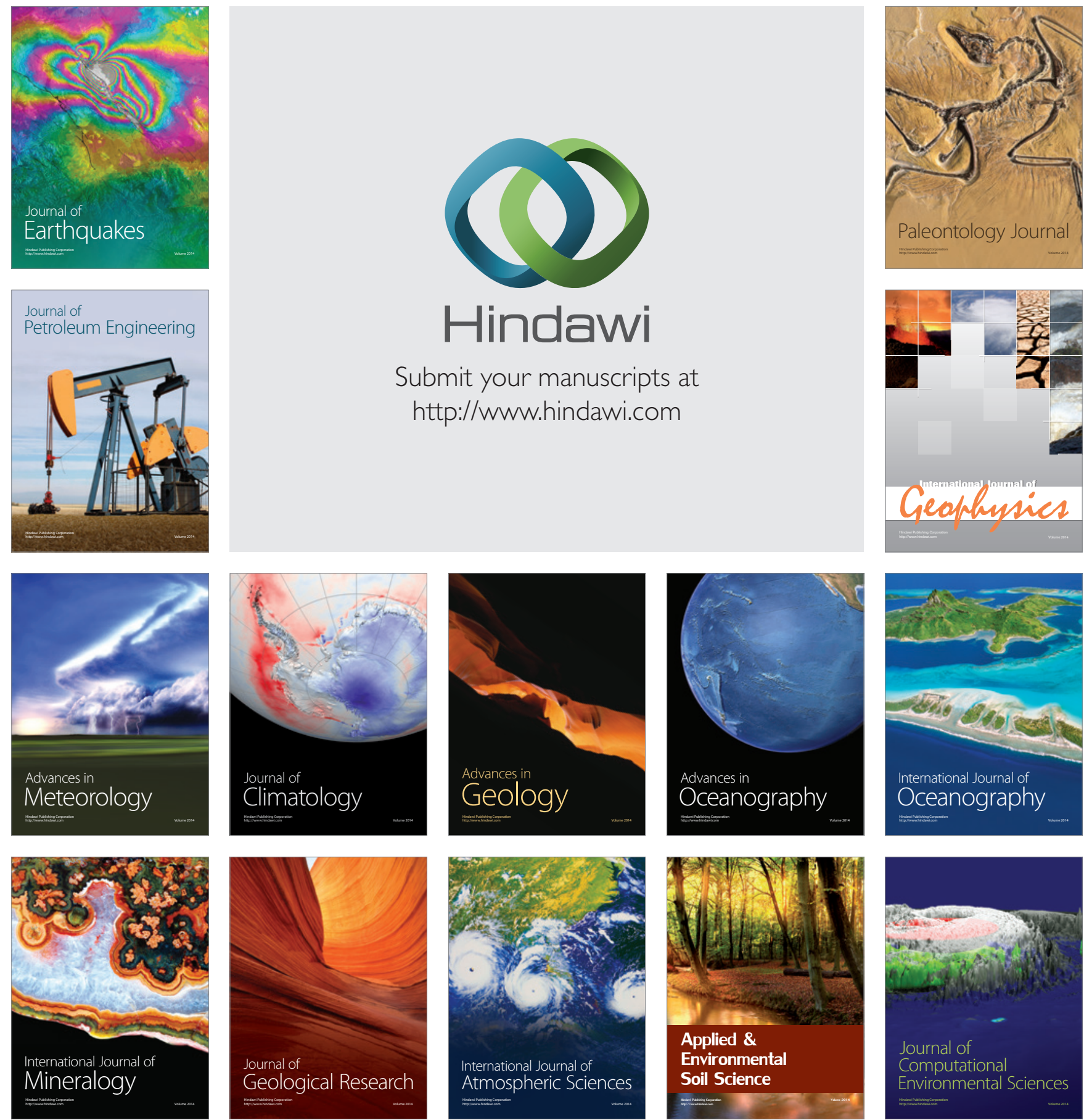